\title{
The future of electricity generation in Australia - a case study of New South Wales
}

\author{
Tim Nelson* \\ Level 23, 200 George Street \\ Sydney, NSW, 2000 \\ December 2017
}

\begin{abstract}
The Australian electricity industry has found itself the subject of an intense political debate. At the centre is the role of coal-fired generation. Wholesale electricity prices have risen substantially as a result of a 'disorderly' closure of ageing coal-fired power stations. The most economic form of new generation technology in Australia is wind on a levelised cost of energy (LCOE) basis. However, new wind generation must be 'firmed' to address variability in output. This has led to calls by politicians for government investment in new coal-fired power stations. The purpose of this article is to consider market dynamics and articulate an 'optimal plant mix' solution. Importantly, the analysis finds that generation will need to be increasingly 'flexible' to complement increased deployment of variable renewable resources. Flexible generation will support the continued efficient operation of the contract market and robust retail competition. Such an outcome will facilitate reliable and competitively priced energy while reducing emissions consistent with Australia's international obligations.
\end{abstract}

Keywords: electricity markets; climate change; renewable generation JEL Codes: D04, D47, Q40, Q41, Q48

\section{Introduction}

Australia's National Electricity Market (NEM) is an energy-only gross wholesale pool. The operation of an energy-only market is well documented by Simshauser (2010). For such a market to be sustainable it must facilitate an 'optimal mix' of generators recovering their fixed (capacity) and variable (fuel and operating) costs over the business cycle. Early studies of the NEM concluded that it had produced significant economic benefits (see Parer, 2002, as an example) despite concerns about revenue adequacy for generators (Simshauser, 2010).

From 2001 onwards, Australian policy makers introduced a number of often overlapping policies aimed at reducing greenhouse gas emissions and increasing the penetration of renewable energy. These included: the Mandatory Renewable Energy Target (MRET); the Large Scale Renewable Energy Target; Premium Feed-in Tariffs (FiT) for embedded generation; the NSW Greenhouse Gas Abatement Scheme; the Clean Energy Act (carbon pricing); the 13\% (subsequently 18\%) Queensland Gas-fired Electricity Generation Scheme; and various capital subsidies for solar hot water and embedded solar PV generation. Nelson et al (2010) provide an overview of the various types of climate change and renewable energy policies which have been introduced over the preceding two decades.

\footnotetext{
- Tim Nelson is Chief Economist at AGL Energy Ltd and an Associate Professor at Griffith University. All views, errors and omissions are entirely the responsibility of the author. Correspondence to tanelson@ agl.com.au.
} 
These climate change and renewable energy policies facilitated enormous investment in new generation capacity. Nelson et al (2015) found that around $16 \mathrm{GW}$ of new investment has been facilitated by climate change policies in Australia. But ageing 'firm dispatchable' capacity has been withdrawn from the NEM in significant quantities. As low short-run marginal cost (SRMC) renewable plant reduced wholesale prices, ageing and inflexible (but firm and dispatachable) coal-fired plants have been retired, resulting in a sudden and dramatic upward shift in wholesale electricity prices.

A relatively unexplored but critical shortcoming of energy-only markets in a 'high penetration' renewables system is the interaction with forward derivative markets. In 'restructured' markets with retail competition, a liquid forward market is critical to facilitate price risk mitigation. As an intermittent energy source, renewables (ex-hydro) are unable to sell financial derivative products to retailers. As renewable grid penetration increases, an increasing proportion of the load is traded without price risk mitigation products in place. These issues are becoming apparent in high renewable penetration markets such as South Australia.

A blackout in South Australia on 28 September 2016 resulted in the Australian Government initiating an inquiry into energy policy, led by Australia's Chief Scientist (Finkel et al, 2017). The review provided fifty recommendations to government. Arguably the two most important recommendations were the introduction of a 'Clean Energy Target' and a 'Generator Reliability Obligation'. These two obligations were thought to deliver on the objectives of reliability, affordability and reduced greenhouse emissions by incentivising investment in low-emissions electricity supply and ensuring that participants in the market supported the forward derivatives market to ensure reliable supply and liquidity that facilitates ongoing retail market competition.

In late 2017, the Commonwealth Government ruled out implementing the Clean Energy Target and instead developed the 'National Energy Guarantee'. This policy is effectively a 'baseline and credit' scheme which would incentivise electricity retailers to source low-emissions generation to meet an emissions baseline consistent with Australia's international obligations articulated at COP21 in 2015, a 26-28\% reduction in emissions by 2030 relative to 2005 levels. At the same time, retailers would also be required to demonstrate support for 'reliability' by adequately contracting for 'firming generation'. It is thought that such a policy could facilitate the ambitious targets of Victorian and Queensland state governments where policies to achieve $40 \%$ and $50 \%$ renewable energy penetration, by 2025 and 2030 respectively, have been set.

In the middle of all this has been an intense political debate about the Liddell power station in New South Wales. The owner, AGL Energy, announced in 2015 that the 2,000 MW coal-fired power station would close in 2022 as a result of both its age and its emissions profile being inconsistent with the Commonwealth Government's commitment to playing its part in keeping global warming limited to 2 degrees Celsius (AGL Energy, 2015; AGL Energy, 2016). A number of Commonwealth Members of Parliament (MPs) have stated that AGL is 'shorting the market' and that it should be 'forced to keep the power station operating' (ABC, 2017). AGL has committed to developing a '90 day plan' for investment in new capacity and energy equivalent to that required to meet any gaps caused by the closure of the Liddell power station.

The purpose of this article is to consider the most appropriate investment for new supply side infrastructure in the Australian market given: changing demand dynamics; technology costs; and the need to reduce greenhouse gas emissions. Section 2 articulates the different market dynamics of the U.S. and Australia as they relate to closure of coal-fired power stations. An overview of the New South Wales electricity market and changing electricity demand and technology costs is presented in Section 3. An 'optimal plant mix' solution is modelled in Section 4 with other important considerations for investors evaluated in Section 5. Concluding remarks are provided in Section 6. 


\section{Disorderly exit of coal-fired power stations - a contrast with the U.S.}

Australia has experienced a 'disorderly' transition to renewables as existing ageing coal-fired power stations have been closed. Prices were significantly below long-run average cost for many years due to oversupply created by flat underlying energy demand and new supply of renewable energy driven by climate change policies. Eventually, the economic pressure of relatively low wholesale electricity prices led to the disorderly withdrawal of significant quantities of capacity. ${ }^{1}$ The closure of capacity is shown in Table 1.

Table 1: Power station closures in National Electricity Market

\begin{tabular}{cccccc}
\hline State & Power station & Coal type & Commissioned & Closed & Capacity (MW) \\
\hline NSW & Munmorah & Black & 1969 & 2012 & 600 \\
NSW & Redbank & Black & 2001 & 2014 & 143 \\
NSW & Wallerawang C & Black & 1976 & 2014 & 1,000 \\
VIC & Morwell & Brown & 1958 & 2014 & 189 \\
VIC & Angelsea & Brown & 1969 & 2015 & 160 \\
QLD & Collinsville & Black & 1968 & 2012 & 180 \\
QLD & Swanbank B & Black & 1970 & 2012 & 500 \\
SA & Northern & Brown & 1985 & 2016 & 546 \\
SA & Playford & Brown & 1960 & 2016 & 240 \\
VIC & Hazelwood & Brown & 1964 & 2017 & 1,600 \\
\hline
\end{tabular}

Importantly, very little notice of closure was provided by any of the power station owners. In the case of Hazelwood, Northern and Playford, less than one year of notice was given.

Unsurprisingly, forward contract electricity prices increased substantially. With such little notice of closure, there was no time for new generation to be built. Importantly, 'firm dispatachable' capacity is still required to complement the significant penetration of wind generation within the Victorian and South Australian regions. The total closure of thermal capacity and investment in new renewable and gas-fired infrastructure is presented in Table 2. It is clear that investment in new 'firm dispatachable' capacity has not kept pace with capacity withdrawals of ageing coalfired power stations since 2013.

\footnotetext{
${ }^{1}$ It is ironic that the 'merit-order effect' which has played a contributing role in the disorderly transition to renewables was at one time celebrated by some commentators as a way to permanently reduce prices. Felder (2011) demonstrated conclusively that in contrast to popular public perception, it is not welfare enhancing. Felder (2011, p. 34) sums up this apparent economic contradiction succinctly, '..if all electricity was provided by out-of-market technologies wholesale energy prices would be near zero, yet consumer electricity costs would increase to cover the additional costs of these technologies, thereby indicating that there was something amiss.' In other words, the 'merit-order effect' must be transitory in nature.
} 
Table 2: New capacity and coal-fired capacity withdrawals in Australia

\begin{tabular}{cccccccc}
\hline $\begin{array}{c}\text { Year of } \\
\text { Exit/Entry }\end{array}$ & \multicolumn{2}{c}{ Coal Retirements } & \multicolumn{3}{c}{ Gas Plant Entry } & \multicolumn{2}{c}{ Renewables Entry } \\
\hline & No. of plant & $\begin{array}{c}\text { Capacity } \\
\text { (MW) }\end{array}$ & $\begin{array}{c}\text { No. of } \\
\text { plant }\end{array}$ & $\begin{array}{c}\text { Total } \\
\text { (MW) }\end{array}$ & $\begin{array}{c}\text { CCGT } \\
\text { (MW) }\end{array}$ & $\begin{array}{c}\text { No. of } \\
\text { plant }\end{array}$ & $\begin{array}{c}\text { Capacity } \\
\text { (MW) }\end{array}$ \\
\hline $2005-2012$ & 2 & 740 & 31 & 8,674 & 2,546 & 112 & 2,640 \\
$2013+$ & 9 & 4,656 & 4 & 218 & 52 & 49 & 2,422 \\
Total & 11 & 5,396 & 35 & 8,892 & 2,598 & 161 & 5,062 \\
\hline Av. Age & \multicolumn{3}{c}{42 years } & & & & \\
\hline
\end{tabular}

Coal-fired generation closure $-18 \%$ of fleet

Source: Simshauser (2017)

It is not unusual for coal-fired power stations to be permanently closed when they are at an advanced age. Figure 1 shows the age of coal-fired power stations operating globally. Very few power stations are operating beyond 50 years of age. Australia's experience, whereby around three quarters of the thermal fleet is beyond its original design life (Nelson et al, 2015), is not too dissimilar from other comparable markets.

Figure 1: Aged of existing coal-fired power stations globally

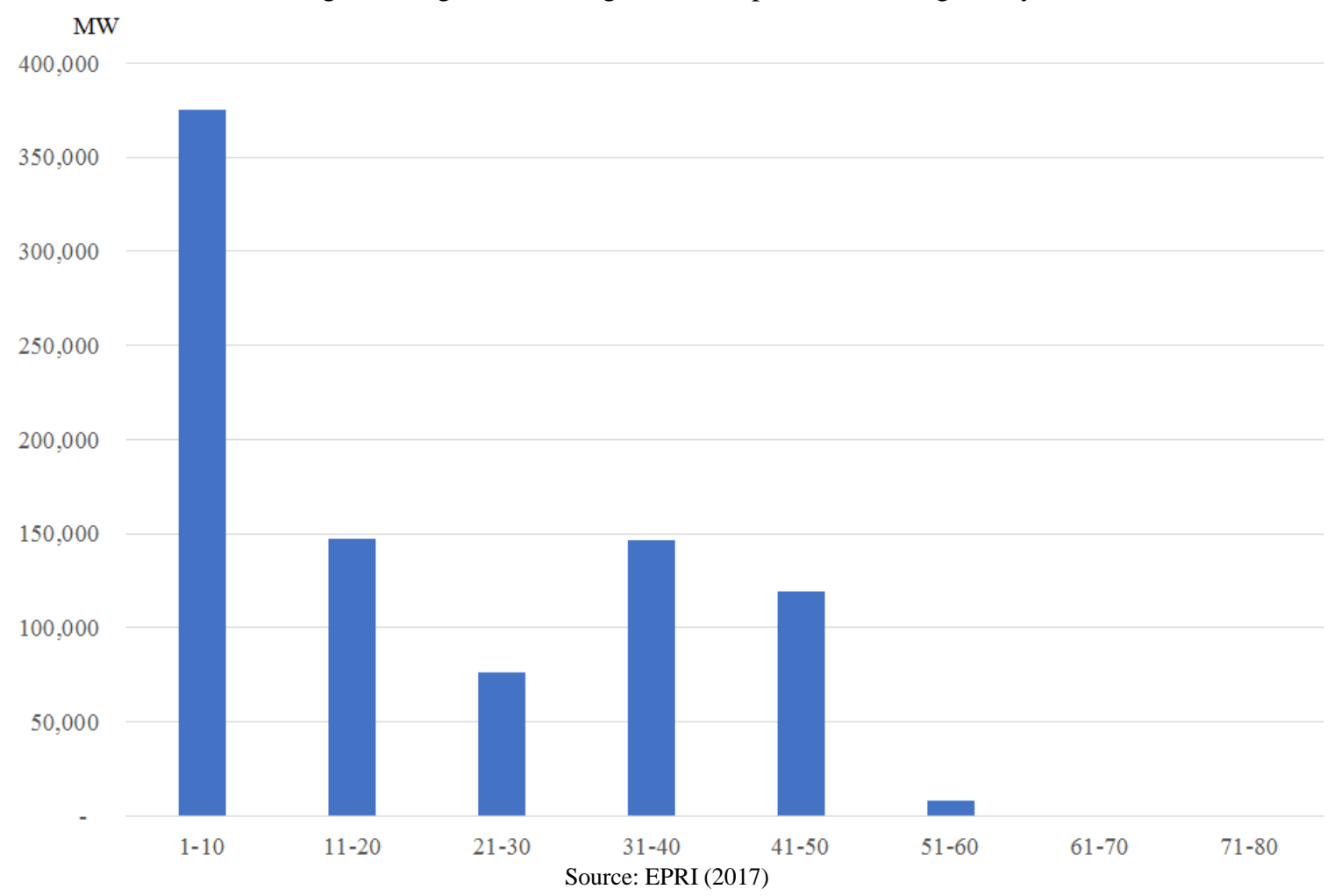

${ }^{2}$ CCGT column is a subset of the total gas capacity column. 
As a contrasting example, in the U.S. there have been similar closures of ageing coal-fired power stations. However, there are two critical differences between the U.S. and Australia: the relatively stable policy environment in the U.S.; and the price and availability of natural gas since the turn of the decade. Australian investors have been reluctant to invest in new mid-merit gas-fired generation (such as combined-cycle turbines) due to both: inherently uncertain long-term energy and climate change policy; and the significant changes that have occurred in domestic gas markets.

Australia's east-coast gas market has changed materially over the past decade. The development of new drilling technologies led to a material increase in reserves from around 3,400 PJ in 2005 to around 50,000 PJ today. This resulted in the construction of three large LNG export facilities in Queensland. There is more than enough gas to physically satisfy domestic demand and current LNG export contracts for at least twenty years. But the estimated marginal cost of production for these resources is around $\$ 6 / \mathrm{GJ}$. Beyond around 50,000 PJ there is a significant step-change in estimated costs with a range of between $\$ 7 / \mathrm{GJ}$ and $\$ 9 / \mathrm{GJ}$, reflected in Figure 2. The same technological revolution that has unlocked low-cost shale gas resources in the U.S. has produced the perverse outcome in Australia whereby higher-cost gas resources (from coal-seam gas) set the marginal cost of gas utilised in gas-fired electricity generation infrastructure.

Figure 2: Aggregate supply curve for east-coast Australian gas market

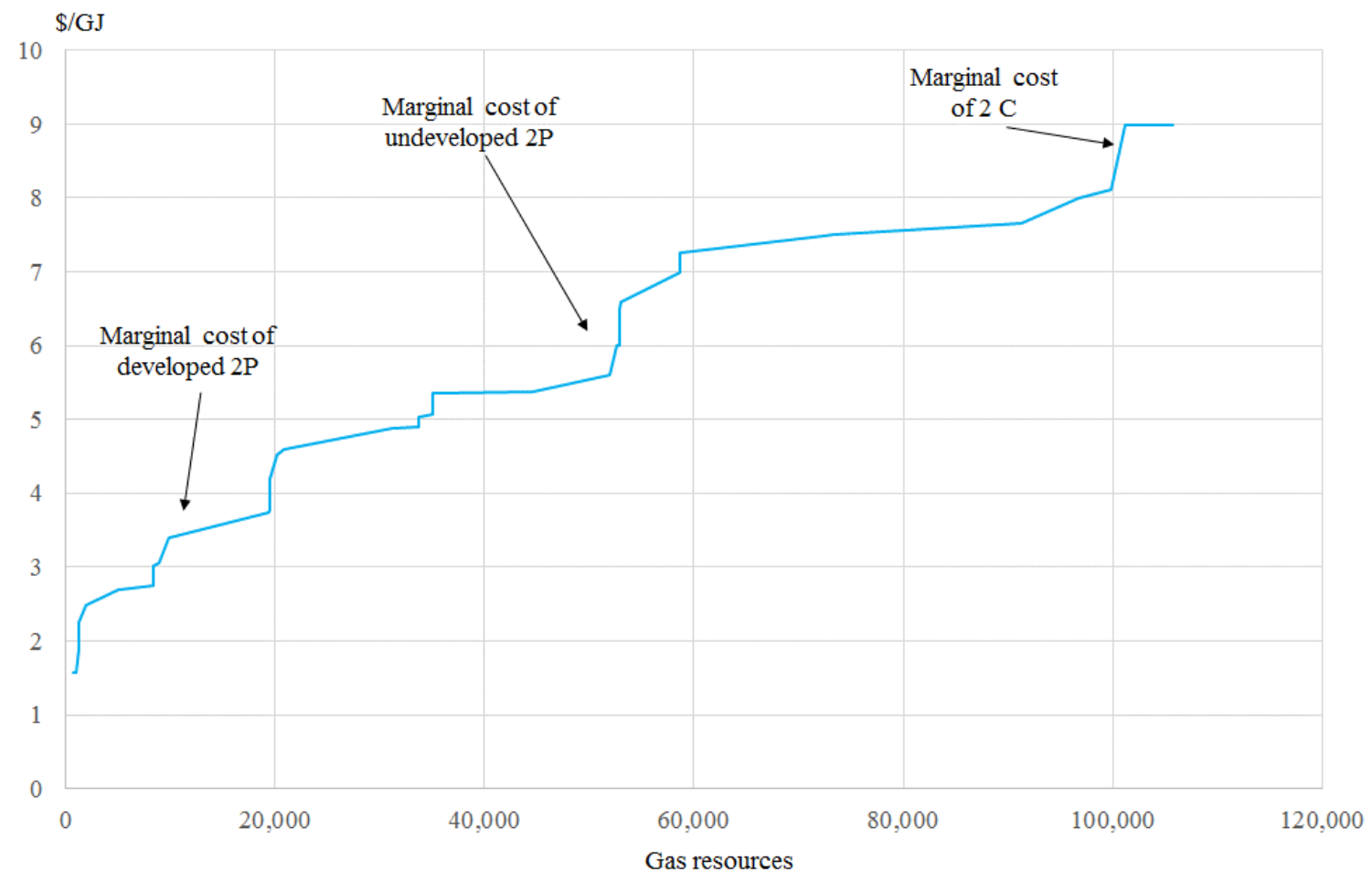

Source: Adapted from AEMO (2017)

But in the U.S., access to low-cost shale gas has resulted in significant investments in new gasfired capacity. The retirements of U.S. coal capacity and investment in new renewable and gasfired capacity is presented in Table 3. It is evident that there has been more investment in new renewable and gas-fired capacity than coal withdrawals, a direct contrast to the outcome in Australia. 
Table 3: New capacity and coal-fired capacity withdrawals in U.S.

\begin{tabular}{|c|c|c|c|c|c|c|c|}
\hline \multirow{2}{*}{$\begin{array}{c}\text { Year of } \\
\text { Exit/Entry }\end{array}$} & \multicolumn{2}{|c|}{ Coal Retirements } & \multicolumn{3}{|c|}{ Gas Plant Entry } & \multicolumn{2}{|c|}{ Renewables Entry } \\
\hline & No. of plant & $\begin{array}{c}\text { Capacity } \\
\text { (MW) }\end{array}$ & $\begin{array}{c}\text { No. of } \\
\text { plant }\end{array}$ & $\begin{array}{c}\text { Capacity } \\
\text { (MW) }\end{array}$ & $\begin{array}{c}\mathrm{CCGT}^{3} \\
(\mathrm{MW})\end{array}$ & $\begin{array}{l}\text { No. of } \\
\text { plant }\end{array}$ & $\begin{array}{l}\text { Capacity } \\
\text { (MW) }\end{array}$ \\
\hline $2005-2012$ & 245 & 11,257 & 648 & 81,775 & 72,925 & 1,500 & 57,449 \\
\hline $2013+$ & 384 & 50,367 & 241 & 36,183 & 14,490 & 2,042 & 44,998 \\
\hline Total & 629 & 61,624 & 889 & 117,958 & 87,416 & 3,542 & 102,447 \\
\hline Av. Age & & 52 years & & & & & \\
\hline Coal-fired & tion clo & $18 \%$ of $\mathrm{f}$ & & & & & \\
\hline
\end{tabular}

In summary, the 'disorderly' transition in Australia has resulted in investment in flexible midmerit generation of only 0.5 times the coal capacity withdrawal. The relative high price of gas and inherently uncertain policy environment have played a key role in this outcome. This can be contrasted with the U.S. where the ratio is 1.9 times of gas plant investment (1.4 times CCGT alone). These summary statistics are presented in Table 4.

Table 4: Australian and U.S. investment ratios in gas/renewables relative to coal exit

\begin{tabular}{cccccc}
\hline & Coal exit & $\begin{array}{c}\text { Average Exit } \\
\text { Age }\end{array}$ & $\begin{array}{c}\text { Gas Plant } \\
\text { Entry Ratio }\end{array}$ & $\begin{array}{c}\text { CCGT } \\
\text { Component }\end{array}$ & $\begin{array}{c}\text { Renewables } \\
\text { Plant Entry } \\
\text { Ratio }\end{array}$ \\
\hline $\begin{array}{c}\text { Australia } \\
\text { USA }\end{array}$ & $18 \%$ & 42 years & $1.6 x$ coal exit & $0.5 x$ coal exit & $0.9 x$ coal exit \\
& $18 \%$ & 52 years & $1.9 x$ coal exit & $1.4 x$ coal exit & $1.7 x$ coal exit \\
\hline \multicolumn{5}{c}{ Source: Simshauser (2017) }
\end{tabular}

Figure 3: Projects under construction and cumulative capacity in 2017

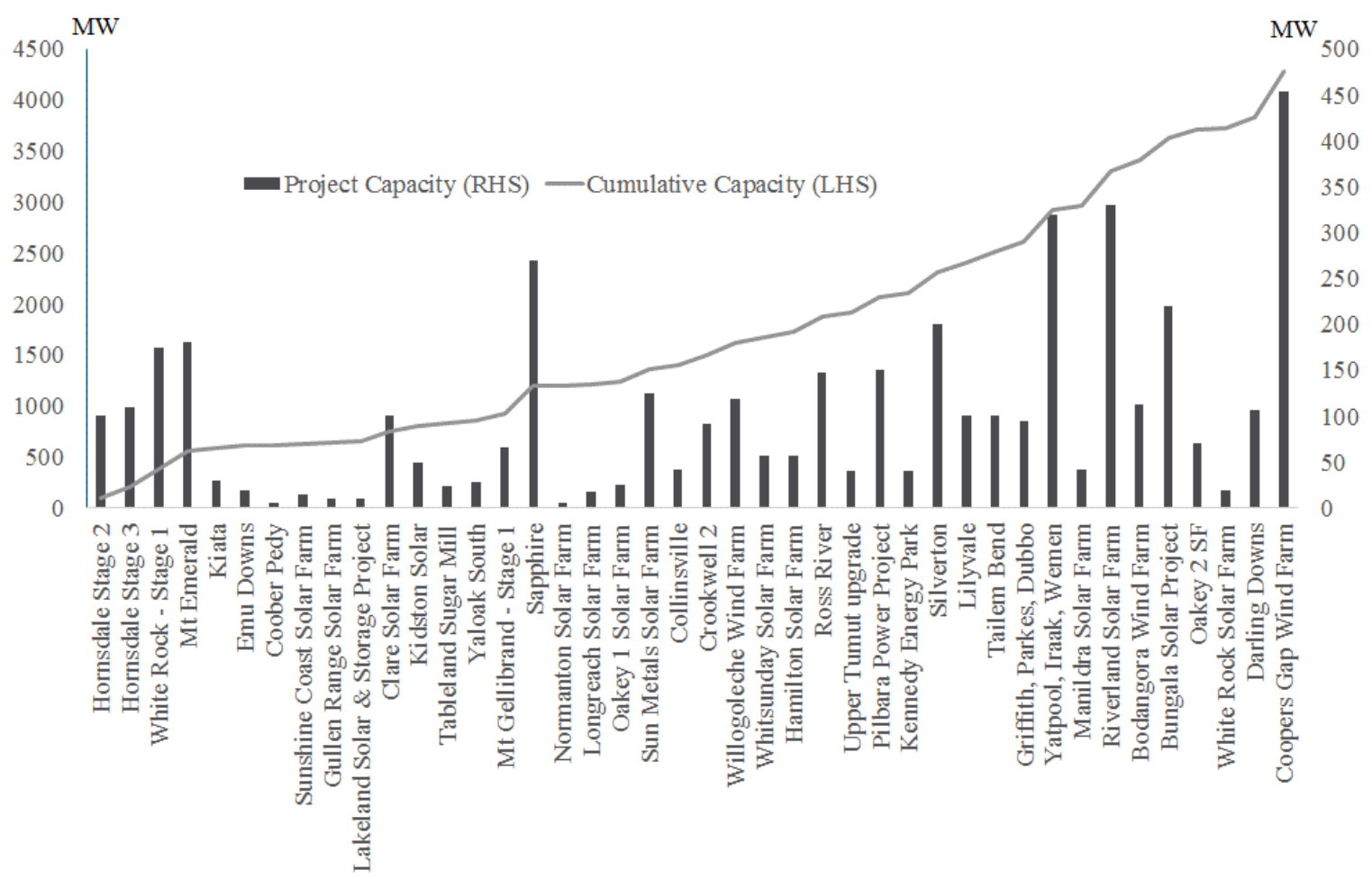

Source: Compiled from industry sources

\footnotetext{
${ }^{3}$ CCGT column is a subset of the total gas capacity column.
} 
Importantly, the high wholesale prices created by this 'disorderly' transition have resulted in significant investment in new renewable energy. As at end 2017, around $4 \mathrm{GW}$ of new capacity (mainly wind and solar) is under construction throughout the east-coast National Electricity Market. The projects and their cumulative capacity are presented in Figure 3. Such investment has been incentivised by both high wholesale prices and the relatively robust price of Large-Scale Generation Certificates (LGCs) under Australia’s 20\% Renewable Energy Target.

But while there are significant investments being made in wind and solar, there has not been the same investment in new 'firm' capacity that is equivalent to the thermal capacity being withdrawn. It is this lack of forthcoming investment in 'firm' capacity that has created intense focus on the New South Wales market and the impending closure of the Liddell power station in 2022. While nearly 9,000 MW of new gas-fired capacity has been added to the system since 2003 , there have been concerns that this is not sufficient to ensure reliability given demand growth between 2003 and 2010, the existing withdrawal of around 5,000 MW of coal-fired capacity through closures and the impending closure of the Liddell power station in 2022.

\section{Overview of the New South Wales electricity market}

The New South Wales electricity market is a summer peaking system with 'baseload' demand of around 5,500 MW and peak demand of around 14,000 GW. The market is serviced by 10,160 MW of coal, 567 MW of CCGT (and equivalent plant) and 4,236 MW of OCGT and hydro. The load duration curve for the FY17 period and a stylised representation of the generation mix is presented in Figure 4.

Figure 4: New South Wales electricity market

Demand (MW)

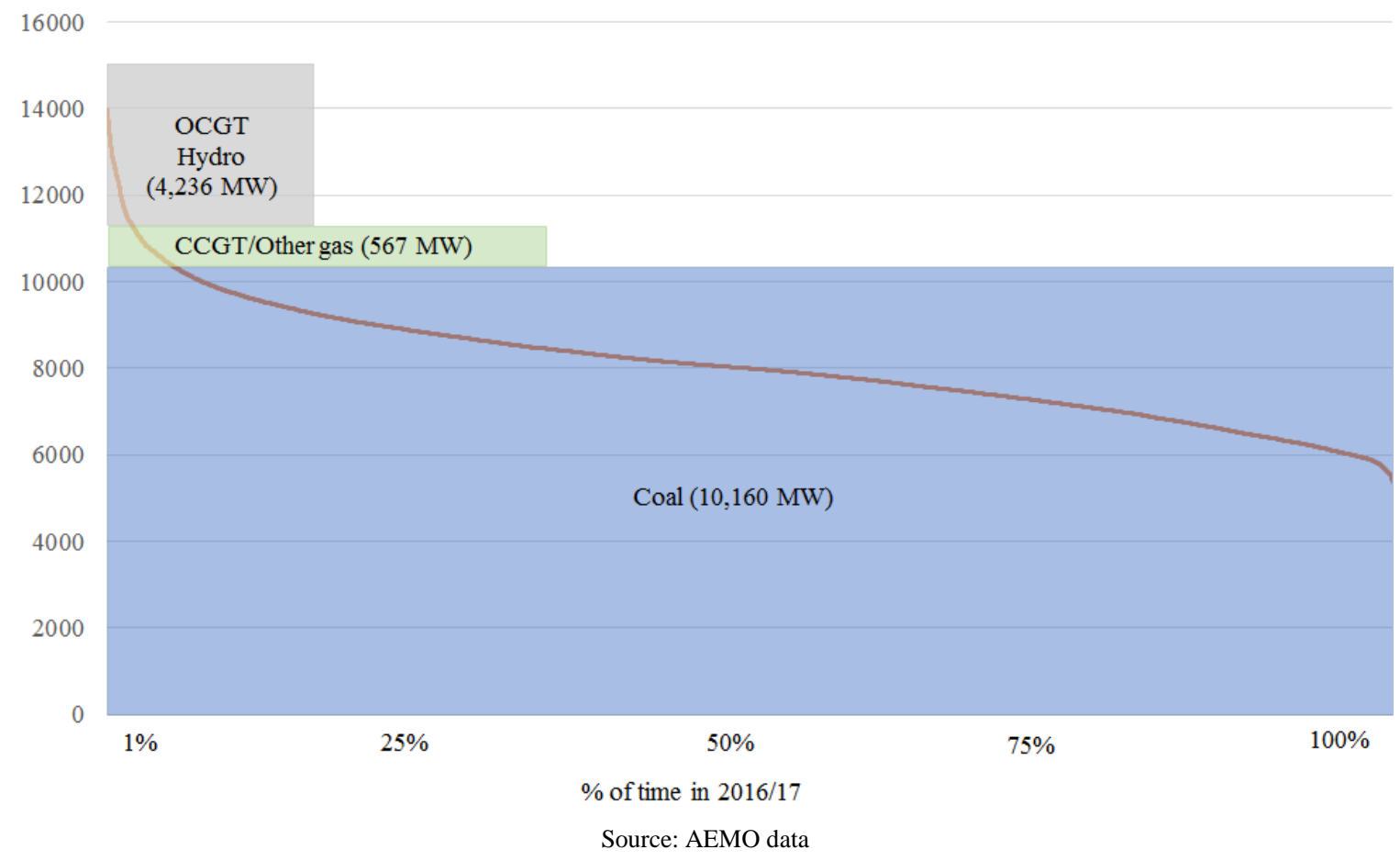


In addition to climate change considerations, there are two key factors driving a shift in generation investment: declining energy demand; and a significant reduction in energy production costs of solar and wind technologies. Firstly, there has been a separation in the growth of underlying energy demand and peak demand. Peak demand has continued to grow while underlying energy demand has been declining since 2010. The Australian Energy Market Operator (AEMO) has forecast that annual energy demand will decline from 67,958 GWh in 2017 to $65,976 \mathrm{GWh}$ in 2022 . At the same time, peak demand is expected to remain at current levels or even increase marginally. In summary, the market requires less energy but the same capacity. This has obvious and non-trivial implications for the type of generation that is required to service the system.

The other key factor driving a shift in generation investment is the material reduction in capital costs for new solar and wind technologies. Appendix 1 provides a summary of key power plant parameters for various technologies in 2007, 2012 and 2017. Utilising a standard power plant financial model (see Simshauser, 2017), an estimate of the fixed and variable costs of various technologies are presented in Figure 5.

Figure 5: Long-run marginal cost of energy for different generation technologies

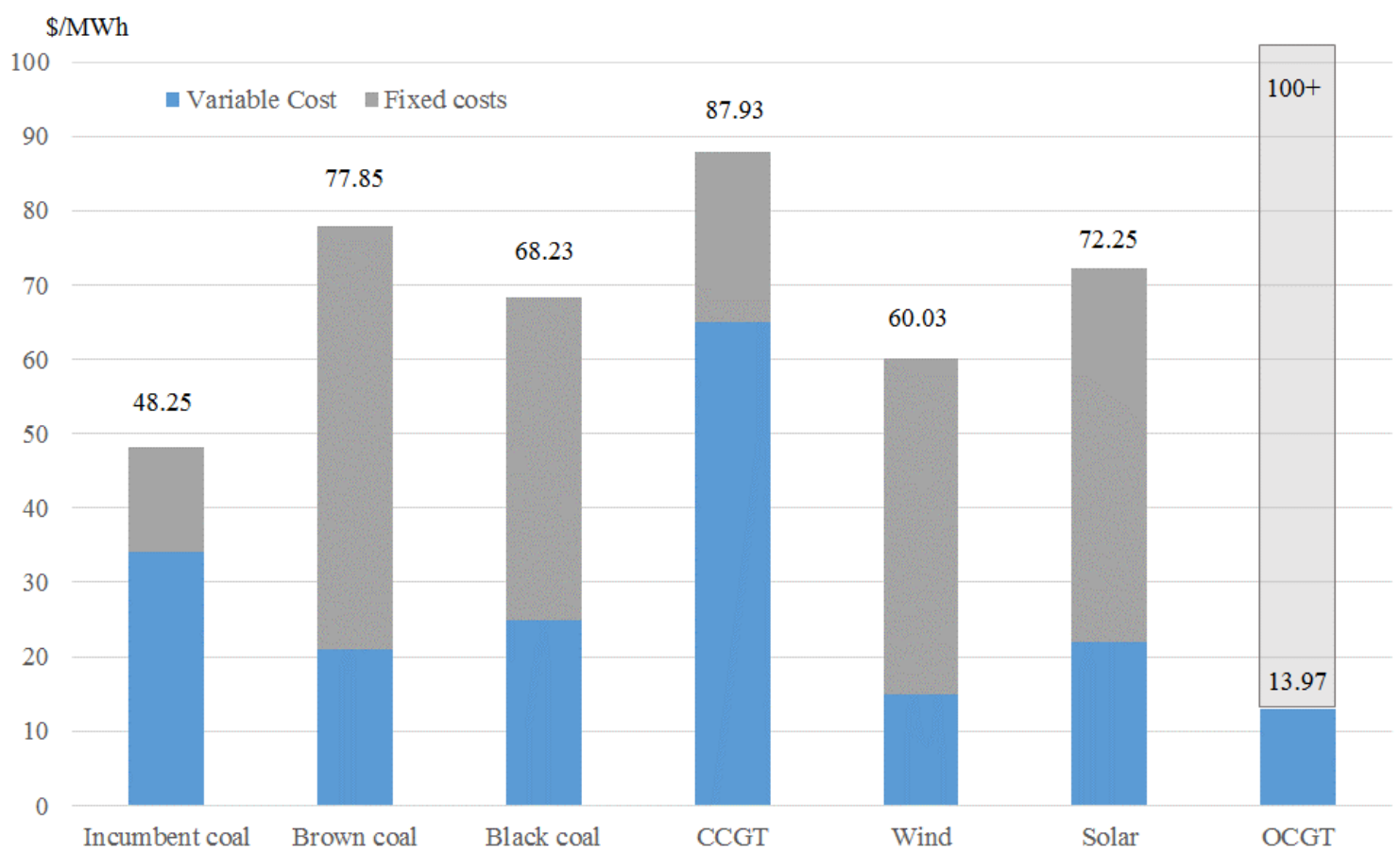

Source: Adapted from Simshauser (2017)

Figure 5 demonstrates that the most economic form of energy production in Australia is now wind generation with a long-run marginal cost of around \$60 per MWh. This is around 12\% cheaper than black coal generation and around $22 \%$ cheaper than brown coal generation. Gas is significantly more expensive as a result of the factors discussed in the previous Section. In fact, at $\$ 8$ per GJ fuel cost, a CCGT has a long-run marginal cost of $\$ 87.93$ per MWh, around $31 \%$ more expensive than wind. Importantly, there is another key feature of wind and solar that has attracted investors. They are able to be installed in smaller, more modular formats than conventional thermal high capacity factor plant. This allows investment to be spread across technologies and regions providing some diversification of risk when compared to the minimum scale required to make a gas-fired or coal-fired project viable. Unsurprisingly, there is 1,367 MW of existing and new solar and wind projects in the New South Wales electricity system. 
The combination of stable or rising peak demand, declining underlying energy demand and increased output from variable renewable generators has distinct implications for the type of investment required to replace the Liddell power station. The area under the load duration curve that needs to be served by 'dispatchable' generation is decreasing as a result of falling energy demand and increased output from variable renewable resources. Given the same (or even an increase in) capacity is required but the amount of energy needed from 'dispatachable' generation is lower, the type of plant required is likely to shift from inflexible coal plant to more 'flexible' gas-fired plant, better suited to operating at a lower capacity factor. This is reinforced by the increasing need for plant to 'complement' variable renewable resources when they are not producing due to a temporary lack of wind or solar resources. A stylised summary of these changing market dynamics is presented in Figure 6, including the impact of closure of the Liddell power station (which reduces coal fired generation to $8,160 \mathrm{MW}$ ).

Figure 6: Summary of the changing dynamics of the New South Wales electricity market

Demand (MW)

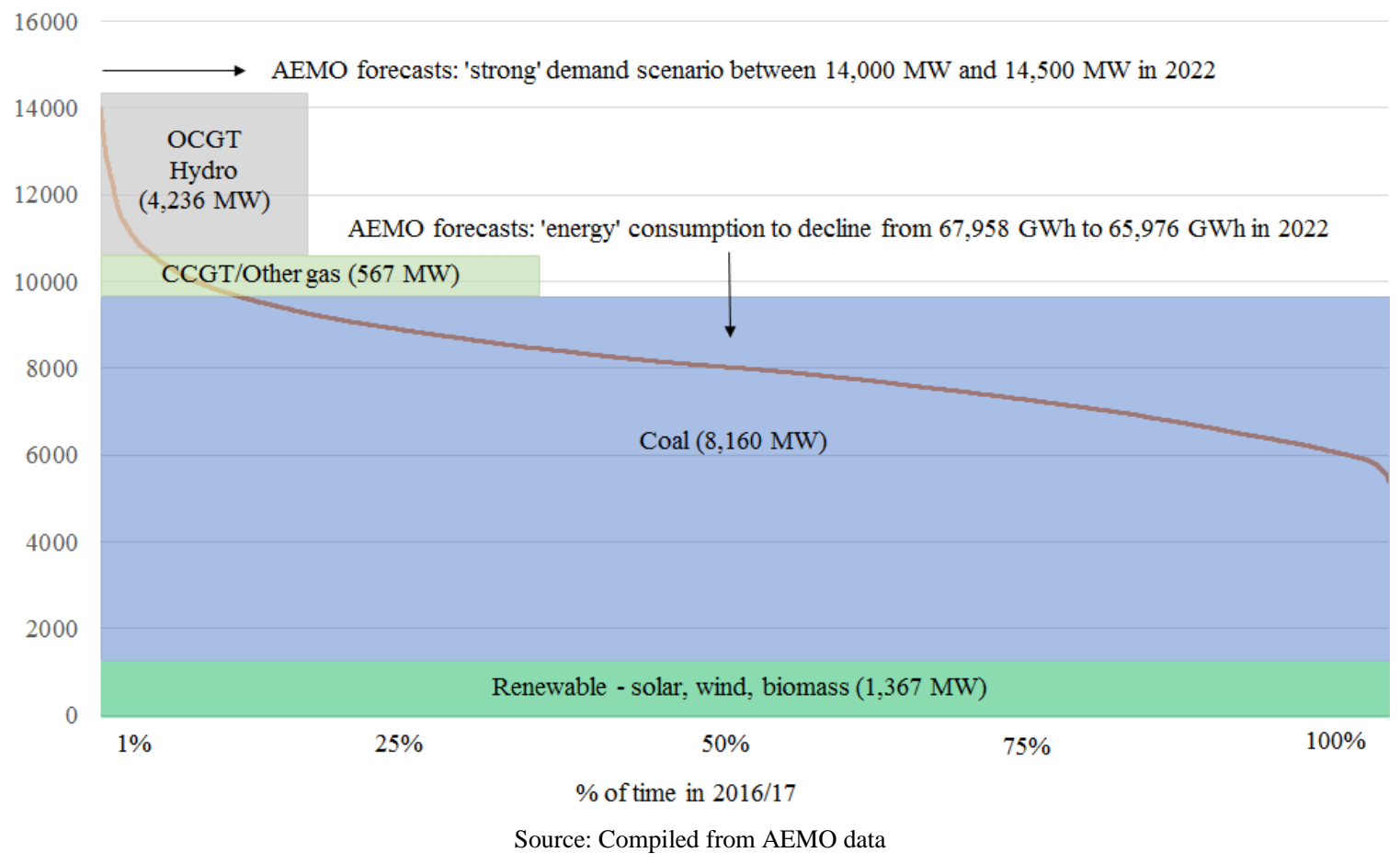




\section{An optimal plant mix solution}

Given the changing market dynamics outlined in the previous Section, an 'optimal plant mix' can be used to determine the incremental investment required given the closure of the Liddell power station in 2022. Our optimal plant mix model is based upon Berrie (1967). The model is consistent with that outlined in Simshauser and Wild (2009) and so it is not reproduced here. In essence, the model utilises the unique economics of three technologies that are 'dispatachable':

- Generation plant with relatively high capital costs but low operating costs is used to meet 'baseload demand' (demand that occurs for most of the time). Historically, black coal generation which is slow to start or shut down has been used to meet baseload demand in New South Wales. Such plant typically operates at a $75-90 \%$ capacity factor and is relatively inflexible.

- Intermediate demand (nominally the higher 'daytime demand') is generally met by plant with medium capital and operating costs and flexible operating capacity (i.e. can be ramped up quickly). Combined cycle gas turbine (CCGT) plant is generally used to meet intermediate demand (assuming gas is available) and typically runs at an annual capacity factor of between 40 and 60 per cent.

- $\quad$ Generation plant with relatively low capital costs but high operating costs is used to meet peak demand (demand that only occurs on the hottest and coldest days of the year, or during power system contingency conditions such as unexpected plant outages). Open cycle gas turbine (OCGT) plant, reciprocating engines or hydro generation which can be ramped up very quickly is used to meet peak demand and typically operates at annual capacity factors of between 5 and 30 per cent.

An optimal plant mix is derived for the FY22 load curve based upon AEMO's assumptions outlined in the previous Section. This optimal plant mix is then contrasted with existing supply (by plant type). Renewable generation is not characterised as baseload, intermediate or peaking but is instead deducted from final demand to form a 'residual load curve' in a manner consistent with Bushnell (2010) and Simshauser et al. (2011). The graphical representation of the 'optimal mix' for 2022 is presented in Figure 7. 
Figure 7: Optimal plant mix calculations for 2022 load curve

Electricity load (MW)

16,000

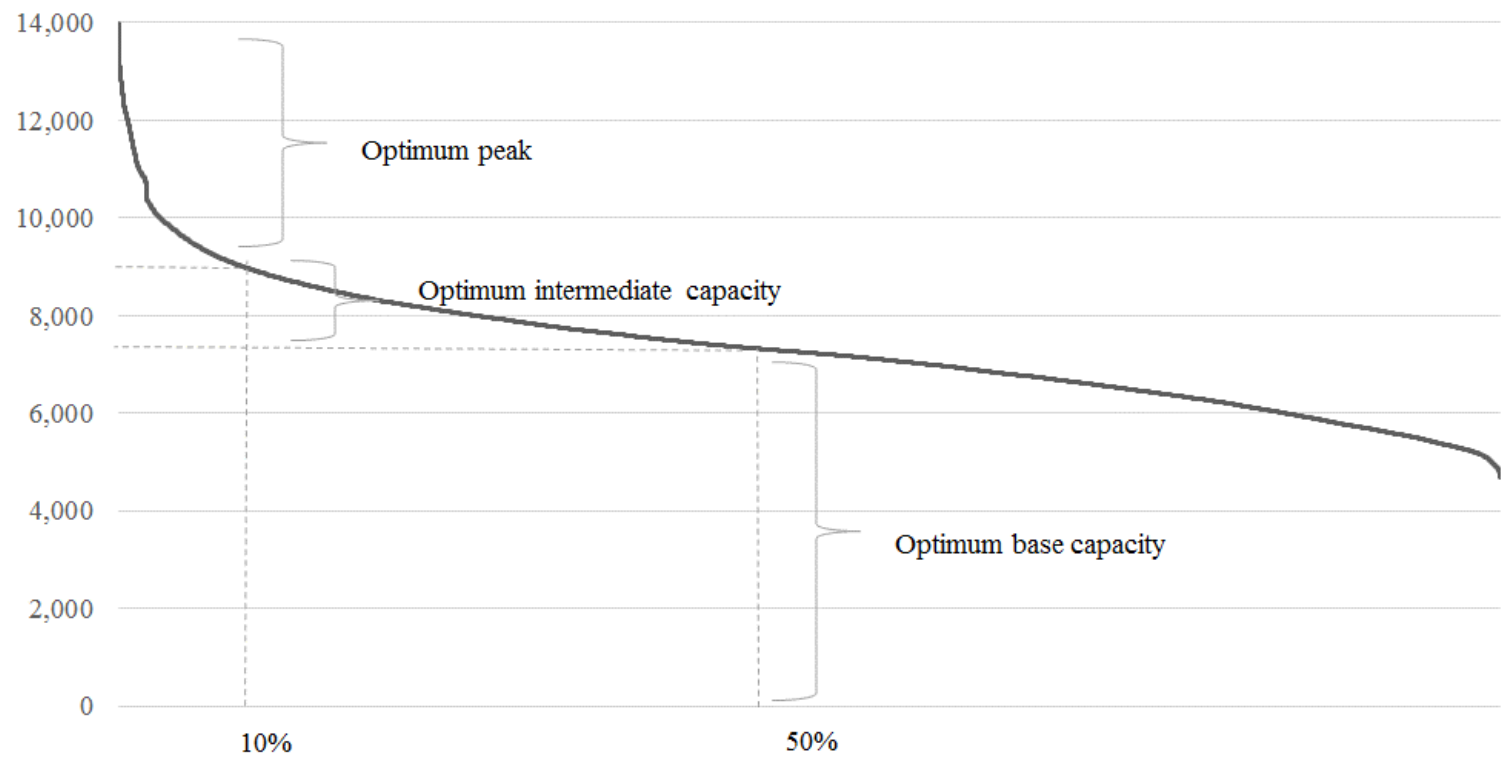

Annual running cost $(\$ / \mathrm{kW})$

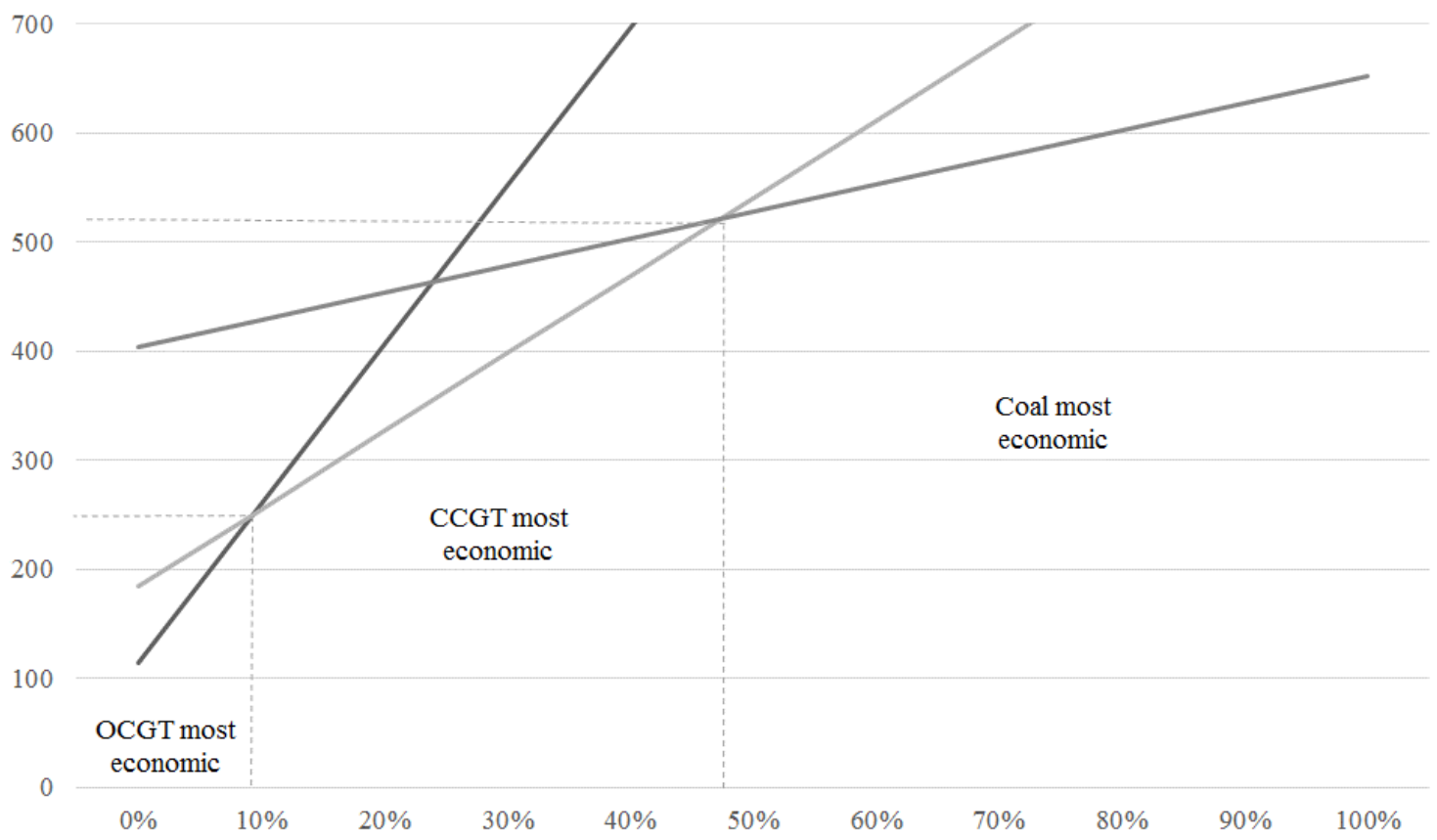


$\underline{\text { Table 5: Optimal plant mix results }}$

\begin{tabular}{ccccc}
\hline Category & Optimal & Actual $(2022)^{4}$ & Imbalance & Weighting \\
\hline Baseload & 7,295 & 8,160 & 865 & overweight \\
Intermediate & 1,669 & 567 & $-1,102$ & underweight \\
Peaking & 5,022 & 4,236 & -786 & underweight \\
\hline & 13,986 & 12,963 & $-1,023$ & \\
\hline
\end{tabular}

The results of the optimal plant mix calculations are presented in Table 5. Given the reduction in energy demand and introduction of variable renewable resources, there is an overweighting of baseload capacity even after the withdrawal of the Liddell power station. That said, both intermediate and peaking generation is underweight with a total required deficit of capacity of $1,023 \mathrm{MW}$. There are two clear conclusions that can be drawn from this analysis. ${ }^{5}$

The market does not suit ongoing operation of the Liddell power station beyond 2022. Even after its withdrawal there is still a clear overweighting of baseload capacity. As such, it is a reasonable conclusion that investment in alternative capacity (given the significant capital expenditure associated with Liddell's ongoing operation beyond $2022^{6}$ ) would be a preferable solution.

- $\quad$ Increased peaking generation is required. Given the overweighting of baseload capacity approximately offsets the underweighting of intermediate capacity, the ongoing optimal investment is in peaking generation. Approximately 1,000 MW of new fast-start capacity is needed. $^{7}$

The optimal plant mix analysis is somewhat dependent upon the price of gas. There are a range of views about the future of gas prices in Australia. In this model, gas prices of $\$ 8$ per GJ have been assumed for mid-merit CCGT plant. While the optimal plant mix analysis indicates that the overweighting of coal and underweighting of CCGT effectively balance each other out, gas is likely to play an important role moving forward. Assuming that Australia meets its COP21 commitments of a 26-28\% reduction in greenhouse gas emissions by 2030 relative to 2005 levels, significant additional investment in renewable energy will be required. 'Dispatchable' plant will be required to complement this increased variable renewable output but gas is preferable to coal due to its relatively quick start and 'flexible' capabilities.

It is important that policy makers and the Australian electricity supply industry consider how best to ensure gas supply is sufficient to fuel increased utilisation of new and existing mid-merit gas plant. Credit Suisse (2017) has found that the most efficient economic solution would be to develop gas import infrastructure (such as Floating Storage Regasification Unit: FSRU technology). Such a development would ensure that the market price floor (created by LNG export capability) is also the market price cap. Gas import infrastructure would create a bidirectional export/import capability and would be likely to significantly improve market liquidity, price transparency and the development of new financial hedging instruments in Australia's east-coast gas markets.

\footnotetext{
${ }^{4}$ This assumes no new investment apart from plant under construction. It also assumes Liddell power station is closed.

${ }^{5}$ This analysis ignores interconnector and reserve margin considerations. Reserve margins would increase the amount of peaking generation required by the system.

${ }^{6}$ AGL has disclosed that best estimates to date indicate capital expenditure of around \$1 billion to extend the life of the Liddell plant for 5 years.

${ }^{7}$ It may be that alternatives to generation such as aggregated demand response are more economic than constructing and operating new peaking generation. This has been ignored in this analysis for simplicity.
} 


\section{Other considerations}

The analysis in the preceding section examines the core energy market dynamics of the New South Wales electricity system and an optimal plant mix. However, there are a range of other considerations that investors are likely to have in relation to the appropriate suite of technologies that should be used to replace the Liddell power station. These include: mitigation of impacts on local community; customer and brand; employee health and safety; and most prominently climate change. A summary of these issues and the potential fit of the different investment options discussed in Section 4 is presented in Table 6.

Table 6: Other considerations relating to investment in generation infrastructure

\begin{tabular}{|c|c|c|c|}
\hline Issue & $\begin{array}{c}\text { Extend Liddell/Build } \\
\text { Coal }\end{array}$ & New Renewables & New Gas Plant \\
\hline $\begin{array}{c}\text { Mitigates climate } \\
\text { change risk }\end{array}$ & $\times$ & $\sqrt{ }$ & $\sqrt{ }$ \\
\hline $\begin{array}{c}\text { Consumer brand } \\
\text { appeal }\end{array}$ & $\times$ & $\sqrt{ }$ & $\sqrt{ }$ \\
\hline $\begin{array}{c}\text { Employee health and } \\
\text { safety }\end{array}$ & $\times$ & $\times$ & $\times$ \\
\hline $\begin{array}{c}\text { Mitigation of impacts } \\
\text { on local community }\end{array}$ & $\sqrt{ }$ & $\sqrt{ }$ & \\
\hline
\end{tabular}

Table 6 shows that across multiple other criteria, investment in new renewables and new gas plant is preferable to extending the operation of the existing Liddell power station or replacing it with new coal-fired generation. Extending the life of a 50 year old power station or investing in new coal capacity is likely to be a difficult proposition to sell to consumers who increasingly are seeking innovative renewable solutions from their energy provider. It is also inherently incompatible with Australia's emission reduction obligations (see AGL, 2016 for more detailed modelling).

\section{Concluding remarks}

This article has considered the future of electricity generation in Australia with a focus on the case study of New South Wales. As a result of Australia having undergone a 'disorderly' transition away from ageing coal-fired generation with significant increases in wholesale electricity prices, there has been intense focus on the future of the Liddell power station. The analysis in this article finds that shifting market dynamics in relation to demand and technology costs results in the most economic new investment option being renewables for energy and gasfired generation for flexible, dispatchable capacity. Extending the life of the Liddell power station beyond 2022 or investing in new coal-fired generation would provide dispatchable but not flexible generation. It would also be inconsistent with Australia's international obligations to reduce greenhouse gas emissions.

In the future, it may be that energy storage (through batteries, pumped hydro or production of hydrogen utilising renewable energy) is a better option than gas-fired generation. Given renewable penetration in the New South Wales market is not sufficient to meet minimum demand, there is little benefit to deploying energy storage. However, this may change as greater levels of investment in renewable energy may see renewable production capacity exceed minimum demand at some point in the future. At this time, storage would be a direct substitute for gas-fired generation. 
It will be important for the Commonwealth and State Governments to agree on a long-term and durable energy and climate change policy mechanism. If implemented in the right manner, the 'National Energy Guarantee' could deliver on the objectives of reliability, affordability and reduced greenhouse emissions. It is important that the policy incentivise investment in lowemissions electricity supply and ensure that generators and retailers support the forward derivatives market to ensure reliable supply and liquidity that facilitates ongoing retail market competition.

\footnotetext{
${ }^{8}$ This assumes that the community benefits from the economic activity associated with extending the operation of the plant. AGL has launched a 'Transition Alliance' with local community representatives to consider alternative uses of the site (see AGL, 2017). 


\section{References}

ABC. (2017), 'Liddell coal-fired power station: Malcolm Turnbull accused of bullying AGL head Andy Vesey', Available online at: http://www.abc.net.au/news/2017-09-12/pm-accused-ofbullying-agl-boss-over-future-of-liddell/8894624, accessed on Tuesday, November 72017.

Australian Energy Market Operator: AEMO. (2017), 2017 Gas Statement of Opportunities, AEMO Publication, Melbourne.

AGL. (2015), AGL Greenhouse Gas Policy, AGL Publication, Sydney.

AGL (2016), Carbon constrained future: AGL's approach to climate change mitigation: a scenario analysis, AGL Publication, Sydney.

AGL. (2017), Rehabilitation: AGL's approach to rehabilitation of power generation infrastructure, AGL Publication, Sydney.

Berrie, T. (1967), 'The economics of system planning in bulk electricity supply', Electricity Review, pp. 425-468.

Bushnell, J. (2010), 'Building blocks: Investment in renewable and non-renewable technologies', Energy Institute at Haas Working Paper, No. 202, Berkeley, California.

Credit Suisse. (2017), Australian East Coast Gas, Credit Suisse Analyst Report, 8 August 2017.

Electric Power Research Institute: EPRI. (2017), Power Plant Statistics, EPRI Publication.

Felder, F. (2011), 'Examining electricity price suppression due to renewable resources and other grid investments', The Electricity Journal, Vol. 24, No. 4, pp. 34-46.

Finkel, A. Moses, K. Munro, C. Effney, T. and O'Kane, M. (2016), Independent Review into the Future Security of the National Electricity Market: Preliminary Report, Commonwealth Government Publication, Canberra.

Nelson, T. Kelley, S. Orton, F. Simshauser, P. (2010), 'Delayed carbon policy certainty and electricity prices in Australia’, Economic Papers, Vol. 29, No. 4, pp. 446-465.

Nelson, T., Reid, C. and McNeill, J. (2015), 'Energy-only markets and renewable energy targets: Complementary policy or policy collision?', Economic Analysis and Policy, Vol. 46, pp. 25-42.

Nelson, T. and Orton, F. (2016), 'Climate and electricity policy integration: Is the South Australian electricity market the canary in the coalmine', The Electricity Journal, Vol. 29, No. 4, pp. 1-7.

Parer, W. (2002), Towards a truly national and efficient energy market, Commonwealth Government Publication, Canberra. 
Pollitt, M. and Haney, A. (2013), 'Dismantling a competitive retail Electricity Market:

Residential Market Reforms in Great Britain', The Electricity Journal, Vol. 27, No. 1, pp. 66-73.

Simshauser, P. Wild, P. (2009), 'The Western Australia power dilemna', The Australian

Economic Review, Vol. 48, No. 4, pp. 342-369.

Simshauser, P. Nelson, T. Doan, T. (2011), 'The boomerang paradox, part II: policy prescriptions for reducing fuel poverty in Australia', The Electricity Journal, Vol. 24, No. 2, pp. 63-75.

Simshauser, P. (2010), 'Vertical integration, credit ratings and retail price settings in energy-only markets: Navigating the Resource Adequacy problem', Energy Policy, Vol. 38, No. 11, pp. 74277441.

Simshauser, P. (2017), 'Australia's National Electricity Market: decarbonisation in a hostile policy environment', Griffith University Working Paper, Griffith University, forthcoming. 


\section{Appendix 1}

Technology parameters in 2007, 2012 and 2017

\begin{tabular}{|c|c|c|c|c|c|c|c|c|c|c|c|}
\hline Technology & Capex & $\begin{array}{l}\text { Installed } \\
\text { Capacity }\end{array}$ & $\begin{array}{r}\text { Generating } \\
\text { Units }\end{array}$ & $\begin{array}{r}\text { Unit Heat } \\
\text { Rate }\end{array}$ & $\begin{array}{r}\text { Unit Fuel } \\
\text { Cost }\end{array}$ & $\begin{array}{r}\text { Capacity } \\
\text { Factor }\end{array}$ & $\begin{array}{r}\text { Fixed O\&M } \\
\text { Cost }\end{array}$ & $\begin{array}{r}\text { Variable } \\
\text { O\&M }\end{array}$ & $\begin{array}{l}\text { Capital } \\
\text { Works }\end{array}$ & $\begin{array}{r}\text { Auxillary } \\
\text { Load }\end{array}$ & $\begin{array}{r}\text { Carbon } \\
\text { Intensity }\end{array}$ \\
\hline & $k j$ & $U S j$ & $\psi O i j$ & $H R j$ & $U F C j$ & $A C F j$ & $F O M j$ & $V O M j$ & $C W j$ & $x j$ & \\
\hline & $(\$ / \mathrm{kW})$ & (MW) & (MW) & $(\mathrm{kJ} / \mathrm{kWh})$ & $(\$ / G J)$ & $(\%)$ & (\$/MW/a) & (\$/MWh) & $(\%)$ & $(\%)$ & $(\mathrm{t} / \mathrm{MWh})$ \\
\hline \multicolumn{12}{|l|}{2007 Inputs } \\
\hline Black Coal & 1,500 & 1,000 & 2 & 9,500 & 1.00 & $90 \%$ & 48,000 & 1.00 & $0.25 \%$ & $7.00 \%$ & 0.86 \\
\hline Brown Coal & 2,250 & 1,000 & 2 & 12,150 & 0.40 & $90 \%$ & 55,000 & 1.30 & $0.25 \%$ & $8.00 \%$ & 1.10 \\
\hline CCGT & 1,200 & 380 & 1 & 7,000 & 3.25 & $85 \%$ & 10,000 & 3.00 & $0.05 \%$ & $2.00 \%$ & 0.63 \\
\hline Wind & 2,100 & 200 & 100 & - & - & $37 \%$ & 40,000 & 1.00 & $0.05 \%$ & $2.00 \%$ & - \\
\hline Solar PV & 4,000 & 20 & - & - & - & $24 \%$ & 62,000 & - & $0.05 \%$ & $0.50 \%$ & - \\
\hline \multicolumn{12}{|l|}{2012 Inputs } \\
\hline Black Coal & 2,250 & 1,000 & 2 & 9,000 & 1.25 & $90 \%$ & 49,250 & 2.00 & $0.25 \%$ & $7.10 \%$ & 0.81 \\
\hline Brown Coal & 3,000 & 1,000 & 2 & 11,613 & 0.40 & $90 \%$ & 60,250 & 4.00 & $0.25 \%$ & $9.60 \%$ & 1.05 \\
\hline CCGT & 1,250 & 380 & 1 & 6,965 & 5.50 & $85 \%$ & 10,000 & 7.00 & $0.05 \%$ & $3.00 \%$ & 0.63 \\
\hline Wind & 2,500 & 450 & 180 & - & - & $39 \%$ & 45,000 & 1.00 & $0.05 \%$ & $2.00 \%$ & - \\
\hline Solar PV & 3,500 & 100 & - & - & - & $28 \%$ & 59,435 & & $0.05 \%$ & $0.50 \%$ & - \\
\hline \multicolumn{12}{|l|}{2017 Inputs } \\
\hline Black Coal & 3,050 & 1,000 & 2 & 8,450 & 1.54 & $90 \%$ & 50,500 & 4.00 & $0.25 \%$ & $7.10 \%$ & 0.76 \\
\hline Brown Coal & 4,000 & 1,000 & 2 & 11,150 & 0.40 & $90 \%$ & 65,500 & 5.00 & $0.25 \%$ & $9.60 \%$ & 1.01 \\
\hline CCGT & 1,500 & 380 & 1 & 6,930 & 8.00 & $85 \%$ & 10,000 & 7.00 & $0.05 \%$ & $3.00 \%$ & 0.63 \\
\hline Wind & 1,787 & 450 & 118 & - & - & $41 \%$ & 50,000 & 1.00 & $0.05 \%$ & $2.00 \%$ & - \\
\hline Solar PV & 1,500 & 100 & - & - & - & $30 \%$ & 56,870 & - & $0.05 \%$ & $1.00 \%$ & - \\
\hline
\end{tabular}

Source: Simshauser (2017) 